\title{
The Nature of Programmed Cell Death
}

\author{
Pierre M. Durand ${ }^{1, \#}$ and Grant Ramsey ${ }^{2}$ \\ ${ }^{1}$ Evolutionary Studies Institute, University of the Witwatersrand, Johannesburg, South Africa \\ ${ }^{2}$ Institute of Philosophy, KU Leuven, Leuven, Belgium \\ \#Corresponding author, ORCID number 0000-0002-9614-1371
}

PMD: pierre.durand@wits.ac.za

GR: grant@theramseylab.org

Received: 14 March 2018 / Accepted: 10 October 2018

\begin{abstract}
In multicellular organisms, cells are frequently programmed to die. This makes good sense: cells that fail to, or are no longer playing important roles are eliminated. From the cell's perspective, this also makes sense, since somatic cells in multicellular organisms require the cooperation of clonal relatives. In unicellular organisms, however, programmed cell death (PCD) poses a difficult and unresolved evolutionary problem. The empirical evidence for PCD in diverse microbial taxa has spurred debates about what precisely PCD means in the case of unicellular organisms (how it should be defined). In this article, we survey the concepts of PCD in the literature and the selective pressures associated with its evolution. We show that definitions of PCD have been almost entirely mechanistic and fail to separate questions concerning what PCD fundamentally is from questions about the kinds of mechanisms that realize PCD. We conclude that an evolutionary definition is best able to
\end{abstract}


distinguish PCD from closely related phenomena. Specifically, we define "true" PCD as an adaptation for death triggered by abiotic or biotic environmental stresses. True PCD is thus not only an evolutionary product but must also have been a target of selection. Apparent PCD resulting from pleiotropy, genetic drift, or trade-offs is not true PCD. We call this "ersatz $P C D . ”$

Keywords Adaptation; Aging; Apoptosis; Price equation; Programmed cell death; Selection; Unicellular organisms 


\section{Introduction}

Unicellular organisms pose unique scientific and philosophical problems. Many of the concepts in evolutionary biology were originally developed with multicellular, sexually reproducing organisms in mind (Sober, 2006). A concept of a species that involves reproductive isolation, for example, may work well for sexual organisms, but does not apply to unicellular organisms that can reproduce through binary fission (Franklin, 2007, Mallet, 1995). One evolutionary concept that spans levels of organization is programmed cell death (PCD) (Ameisen, 1996, Nedelcu et al., 2011). Cell death (at the time its programmed nature was unknown) was first observed as part of normal development in multicellular embryonic tissues (Collin, 1906, Ernst, 1926, Hamburger and Levi-Montalcini, 1949, Kallius, 1931). PCD, and its role in animal ontogeny, was made explicit several decades later (Glücksmann, 1951, Lockshin and Williams, 1964). While there is an obvious cost for the individual cell, PCD is maintained in multicellular life because of clonal relationships, and keeps cell lines from replicating indefinitely. Cell lines capable of indefinite replication can be a liability for the organism. For instance, cancer is a rogue cell lineage, one that lost its PCD function and pullulates at the expense of the organism (Merlo et al., 2006).

In single-celled organisms, members of the species sometimes die not through predation, disease, or other misfortune, but because of PCD. PCD in unicellular life is the ultimate sacrifice for which there is no clear benefit to the dying cell. How might PCD be the result of selection? Should we consider it an adaptation? This debate has been ongoing ever since PCD was found to occur in unicellular organisms (for the latest see Klim et al., 2018).

Many of the existing explanations of PCD in unicellular organisms focus on the phenomenon as either an adaptation or as a side effect of another essential function. Such explanations are generally framed in terms of fitness costs and benefits to individuals, their kin, or groups of conspecifics (Ameisen, 2002, Bayles, 2014, Nedelcu et al., 2011, Pepper et 
al., 2013). PCD has also been considered in broader ecological contexts like phytoplankton ecology (Franklin et al., 2006, Berges and Choi, 2014, Bidle, 2015), the microbial loop (Bidle, 2016, Orellana et al., 2013), microalgal blooms (Vardi et al., 2007), conflict mediation in group formation and evolutionary transitions (Fisher et al., 2013, Hanschen et al., 2018, Kapsetaki et al., 2017, Michod, 2003, Michod and Roze, 2001, Sathe and Durand, 2016), propagule formation in the experimental evolution of multicellularity (Ratcliff et al., 2012), the evolution of different kinds of complexity (Durand et al., 2016), the evolution of aerobic metabolism and the eukaryote cell (Klim et al., 2018, Kaczanowski et al., 2011, Koonin and Aravind, 2002), and as a virus-host arms race (Iranzo et al., 2014).

There are three fundamental questions concerning the nature and evolution of $\mathrm{PCD}$ in unicellular organisms. First, how should we understand the concept of PCD (are there different "kinds" of PCD)? Second, what evidence is there to account for its evolution? Third, by what mechanisms could PCD have evolved? Our focus here is on the first two questions. In what follows, we consider the nature of - and evidence for - the evolution of PCD. We propose an evolution-based concept of PCD and provide definitions for different kinds of death.

\section{The Many Meanings of "Programmed Cell Death"}

There is no standard way of defining PCD in unicellular organisms (Table 1). In many cases, researchers do not explicitly state what they mean, and there has recently been a call to clarify the terms used (Pandey et al., 2018). The definitions of PCD have usually been framed in terms of cellular mechanisms, which could have come about via a range of possible developmental processes or evolutionary histories. The history that formed the mechanism is not, in this case, determinative of whether it is PCD. Instead, all that matters are the characteristics of the mechanism. For example, PCD can be defined as "active, genetically 
controlled, cellular self-destruction driven by a series of complex biochemical events and specialized cellular machinery" (Berman-Frank et al., 2004). However, mechanism-based definitions of PCD can be challenging to formulate. There is "confusion as to how many distinct types of PCD exist" (Reece et al., 2011) and the reliance on mechanistic processes alone does not provide ecological context concerning the origin or function of PCD. There are very few, if any, definitions of PCD in the literature that are explicitly based on the evolutionary history of the mechanism, although the authors' views are often implied. Considering the interpretations of PCD evolution, there are two main versions, one broad and the other narrow. The narrow variant implies that PCD is the result of an adaptation for causing such death. The broad variant includes all forms of PCD with an evolutionary history but does not require direct selection. In addition to PCD as an adaptation, the broad variant includes death resulting from a mechanism that evolved by genetic drift, mutation accumulation, life history trade-offs (Pepper et al., 2013), as an arms race (Iranzo et al., 2014), or as a side effect of some other adaptation (Nedelcu et al., 2011, Ameisen, 2002). There are thus mechanism-based, (broad) evolution-based, and adaptation-based interpretations of PCD. We will argue that in developing a general framework for understanding PCD, a narrow adaptation-based definition is preferable to the alternatives. Before doing so, we need to be clear on what "programmed" means.

\section{What is a Biological Program?}

In biology the word "program" is typically used for a developmental system in which genetically based information is said to "program for" the expression of a trait. The biological usage and etymology implies that the phenotype is the outcome in cells containing such a program. For PCD, however, the term "programmed" is often misleading (Ameisen, 2002). In some instances, the program may never be implemented, and death may be incidental. In 
others, the same (or overlapping) program may lead to a different outcome, like encystation (Khan et al., 2015). Furthermore, even when the program is implemented, the phenotype need not be all-or-nothing (Kroemer et al., 2009). There are degrees of dying. For example, in multicellular tissues, anastasis is the situation where cells lose viability but regain it if conditions improve (Sun and Montell, 2017). A similar scenario plays out in photosynthetic unicellular organisms, where the physiological health and gradual loss of viability that occurs during PCD can be measured by the cell's photosynthetic efficiency (Berges and Falkowski, 1998, Affenzeller et al., 2009). In other words, PCD codes for (1) the potential activation of a molecular pathway that (2) once activated, may result in different evolutionarily significant outcomes: death, encystation, or a transient, graded loss of viability. In addition, when the same PCD stimulus is applied to a clonal population under the same environmental conditions, the program is not activated in all individuals even if they are clones (Moharikar et al., 2006). To complicate the situation even further, the same stimulus that activates the PCD program may also activate an alternate program resulting in sexual reproduction (Nedelcu and Michod, 2003).

Despite the confusion, the term PCD is used universally, and, it seems, is here to stay. It is thus unlikely that introducing another term will be helpful. We emphasize, however, that the term "program" in PCD denotes a system that is probabilistic (the same input does not universally produce the same output), branching (some stages in the execution of the program can lead to a range of future states), and non-discrete (loss of viability can be transient or graded). 


\section{PCD as a Mechanistic Process}

Mechanistically, PCD is distinct from other forms of death. Cells may die if they have suffered physical or chemical damage, or if they have been lyzed by invading viruses (though PCD can also be triggered by viral infection (Vardi et al., 2012)). These forms of death are imposed by external factors and can be unambiguously distinguished from PCD. Death in the absence of PCD can be referred to as incidental death, necrosis, lytic death, non-PCD, or simply death. We prefer the term "incidental death," which indicates that death is incidental to an extrinsic event, contrasting it with intrinsic, genetically encoded PCD.

Another important distinction is that between PCD and cell aging. PCD and aging share some mechanistic features. In the yeast Saccharomyces cerevisiae, for example, the mechanisms overlap both genetically and phenotypically (Herker et al., 2004). But there are also distinctions. Aging is not external to the cell like incidental death but is a passive breakdown of cellular mechanisms. Aging can be delayed by protecting against these harmful processes. PCD, by contrast, is a much more active event. It requires chemical energy and the transcription of effector genes (Engelberg-Kulka et al., 2006), which may or may not be associated with other cellular functions (Berges and Falkowski, 1998). PCD happens rapidly (hours or at most days) and is usually unrelated to cellular age. In aging, the process is gradual, associated with biochemical processes that are unrelated to PCD, and in some instances a function of the number of cell divisions (Laun et al., 2001). Aging can be explained thermodynamically without invoking natural selection, whereas PCD is subject to natural selection. There is a degree of overlap, and the cellular mechanisms involved in aging are of course themselves subject to natural selection, which can affect the character and rate of aging. However, there is an inevitability associated with aging that does not apply to PCD.

The identification of a range of PCD mechanisms in unicellular organisms may suggest that PCD should be defined as a kind of mechanism. Indeed, most of the 
interpretations of PCD provided by researchers are purely mechanistic (Table 1). In some instances, the mechanism-based definitions and nomenclature are tailored to a specific organism, for example, yeast (Carmona-Gutierrez et al., 2018). Defining PCD in mechanistic terms is clearly helpful for unraveling the molecular pathways (Aravind et al., 1999, Durand and Coetzer, 2008, Nedelcu, 2009, Uren et al., 2000), but doing so limits our interpretation of the evolutionary history, especially if one holds that the evolutionary history bears on the question of whether we should count something as genuine PCD. Opposing views about whether a form of cell death is PCD persist even when the mechanism and mode of death are agreed upon. A case in point is the controversy concerning the interpretation of the mazEF death mechanism in Escherichia coli. Some researchers clearly view the mazEF toxinantitoxin system as typical PCD in bacteria (Hazan and Engelberg-Kulka, 2004, Hazan et al., 2004). In contrast, others (Ramisetty et al., 2015, Ramisetty and Santhosh, 2017) assert that “mazEF systems do not confer PCD” (Ramisetty and Santhosh, 2017). They interpret toxinantitoxin (TA) systems like mazEF to be the products of gene level selection. Ameisen has yet another interpretation of TA systems, calling them "addiction molecules" where cells are addicted to the genetic modules encoding the TA system. Loss of a functioning TA module leads to toxin-induced death (Ameisen, 2002).

These conflicts illustrate that even when the mechanisms are the primary target of study, the question of whether they should count as genuine PCD bears crucially on the selection history of the mechanisms. We agree with Reece, Berges and others that "focussing on the mechanistic differences... without the relevant ecological context is not a useful way to progress" (Reece et al., 2011) and that understanding PCD "requires clearer definitions of cell death: definitions that are subject to considerable debate even in taxa that are relatively wellexplored" (Berges and Choi, 2014). We conclude that a definition of PCD based purely on mechanisms will fail to resolve such controversies and argue that mechanism-based 
definitions do not clearly distinguish two important questions: (1) what is PCD (how should it be defined), and (2) what kinds of mechanisms realize PCD?

\section{PCD as an Evolutionary Process}

The evolution of PCD has been tackled from several angles (Ameisen, 2002, Bayles, 2014, Bidle, 2016, Durand et al., 2016, Franklin et al., 2006, Kaczanowski et al., 2011, Koonin and Aravind, 2002, Lewis, 2000, Nedelcu et al., 2011, Pepper et al., 2013, Reece et al., 2011, Iranzo et al., 2014, Klim et al., 2018) although an explicit evolutionary definition is seldom provided. However, we claim that it is the evolutionary history that bears on whether something should be considered true PCD or not. In incidental death (discussed above), death comes about by external triggers. In contrast, there is also death brought about by internal mechanisms and one must look to the evolutionary history of these mechanisms to determine whether the trait is PCD. If the function of causing death has been selected for, it is true PCD. If, on the other hand, the evolutionary history involves selection for a different function pleiotropically linked to the apparent PCD, or if it is not directly linked with selection (e.g., genetic drift), the trait should not be considered true PCD.

Understanding PCD in this way will allow us to sharply distinguish the two questions above (what is PCD? versus which mechanisms realize PCD?) and will help resolve the persistent debates over whether and when PCD is an adaptation. Until now, there has been considerable discussion of how PCD may evolve, both by nonadaptive pleiotropic means (for example Frade and Michaelidis, 1997), and by natural selection (for example van Zandbergen et al., 2010). However, the extensive discussions of the evolution of PCD (Ameisen, 2002, Durand et al., 2016, Nedelcu et al., 2011, Pepper et al., 2013, Ramisetty et al., 2015, Berges and Choi, 2014, Gardner and Kummerli, 2008, Reece et al., 2011, Klim et al., 2018, Koonin and Aravind, 2002) have not always clearly articulated the distinction between these 
questions, and have not offered a definition of PCD that allows for PCD to be defined independently of the mechanisms that realize it.

To examine this distinction more closely, we wish to test possible hypotheses for the evolution of PCD and to consider both adaptive explanations (in which case it is true PCD) and explanations not involving direct selection for the mechanism (what we will label "ersatz PCD”). Genetic drift (Lynch, 2007) and the effects of chance cannot be ignored (Bonner, 2013, Koonin, 2011, Ramsey and Pence, 2016), and the claim that there are instances when programmed forms of death are selected for should be substantiated. Koonin argues that, at the molecular level, many genetic sequences can be a result of neutral evolution: "it survives by sheer chance provided that it is not deleterious enough to be efficiently purged by natural selection" (Koonin, 2016), and that to invoke adaptation the null hypothesis must be falsified. Gardner suggests that this approach is not always necessary, especially if one "mistakes adaptationism for a hypothesis when it is actually a research method" (Gardner, 2017). Van Valen is also critical of arguments that place neutral evolution above adaptation, stating that, "neither the presence nor the absence of adaptation has a privileged status in inference" (van Valen, 2009).

The aim here is not to favor a particular stance on whether adaptation or neutral evolution is more important (for contrasting views see Hendry and Gonzalez, 2008, Sansom, 2003). As Lloyd explains, it is the logic behind the research question that matters (Adaptationism and the Logic of Research Questions: How to Think Clearly About Evolutionary Causes”. Elisabeth A. Lloyd. Biological Theory 10 (4):DOI: 10.1007/s13752015-0214-2 (2015)). Koonin's approach is helpful here because of what it reveals about the nature of PCD. It illustrates the limits of mechanistic definitions, but more importantly, the conclusions demonstrate the importance of distinguishing true PCD from other kinds of PCD based on their evolutionary histories. 


\section{An Adaptation-Based Definition of PCD}

To counteract the suggestions that PCD is due to mechanisms that are not adaptations for death (for example, Proto et al., 2013, Frade and Michaelidis, 1997, Klim et al., 2018, Nedelcu et al., 2011, Ramisetty et al., 2015, Segovia et al., 2003), we will illustrate the differences in evolutionary histories among distinct forms of programmed death and justify our claim for an adaptation-based definition of PCD. There is sufficient evidence that in some instances PCD (1) provides fitness advantages to the group, (2) has been selected for, and (3) that the fitness advantages of PCD are based on the mechanisms that lead to death. We therefore propose that PCD in the microbial world be defined as an adaptation for producing cell death. We refer to instances where PCD evolved pleiotropically, by genetic drift, or life history trade-offs as "ersatz PCD," since it is not true PCD as defined here.

\section{Differentiating the Evolutionary Histories of PCD and Ersatz PCD in Unicellular}

\section{Organisms}

The key advantage of defining PCD as an adaptation for death is that it allows us to better distinguish PCD from other forms of death that result from genetic programs with evolutionary histories different from that of PCD. Autophagy, for example, shares properties with other PCD phenotypes, but we claim that for unicellular organisms with no multicellular stage, it usually represents adaptations that are not related to PCD itself.

Autophagy is common in unicellular eukaryotes (Kiel, 2010). As the name implies, autophagic cells consume themselves - usually to survive nutrient depletion - and is the result of a well-documented genetic program (Kiel, 2010). Autophagy is one of the "different ways to die" (Jiménez et al., 2009) in Dunaliella viridis by genetically encoded mechanisms, but when death occurs in conjunction with autophagy, it is best understood as a by-product of 
a survival mechanism. However, autophagy in multicellular organisms, or in unicellular organisms with a multicellular stage, occurs in response to distinct evolutionary pressures. For example, in the slime mold Dictyostelium discoideum autophagy may occur in response to nutrient depletion (Lam et al., 2007, Luciani et al., 2017, Olie et al., 1998), where it is part of differentiation in the multicellular stage. One should therefore sharply distinguish autophagy in multicellular organisms (or stages) from autophagy in unicellular organisms lacking a multicellular stage. For unicellular organisms with no multicellular stage, autophagy (1) involves specific genetic programs, (2) is a cell-level adaptation to starvation, and (3) can result in death. But in contrast to PCD, autophagy is selected for as a survival strategy, making death an unwanted side effect.

The most common form of PCD in unicellular organisms that is mechanistically distinct from autophagy is referred to as apoptosis, or more accurately, "apoptosis-like" (Kasuba et al., 2015). This form of PCD in unicellular organisms is similar to apoptosis in multicellular organisms (Kerr et al., 1972) and the term "apoptosis-like" was therefore introduced. Apoptosis-like death can be unambiguously distinguished from autophagy (Kasuba et al., 2015, Kiel, 2010, Pérez Martín, 2008), although the two can sometimes occur in parallel (Jiménez et al., 2009). The triggers for apoptosis-like death in unicells include a range of environmental stressors like heat, changes in $\mathrm{pH}$ and salt concentrations, oxidative stress, the presence of toxins or antimetabolites, nitrogen or phosphate depletion, and UV irradiation (see references to individual taxa in Ameisen, 2002, Bayles, 2014, Bidle, 2016, Deponte, 2008, Kaczanowski et al., 2011, Lewis, 2000, Nedelcu et al., 2011, Pepper et al., 2013, Pérez Martín, 2008). The phenotype is also variable. In C. reinhardtii, for example, the cellular ultrastructural changes associated with PCD may be quite different depending on the stimulus (compare the TEM images in Durand et al., 2016, Moharikar et al., 2006). 
In some instances apoptosis-like death may be a by-product (Klim et al., 2018).

However, in cases where apoptosis-like death is a genuine adaptation, there should be higherlevel benefits that can be identified. We use the remainder of this section to do so by asking a series of pointed questions that have been raised in publications, working groups, discussion forums, and by reviewers of grants and manuscript submissions. The answers are used to evaluate the null hypothesis that PCD is a pleiotropic or chance event and to justify our definition of true PCD as an adaptation.

What are the proposed mechanisms by which apoptosis-like PCD may be selected for?

The proposed mechanisms fall naturally into at least five broad categories. First, in parasites PCD has been considered a mechanism for controlling parasite density in the host, thereby increasing host survival and favoring parasite transmission (Al-Olayan et al., 2002, Ameisen, 1996, Debrabant and Nakhasi, 2003, Engelbrecht and Coetzer, 2013, Deponte, 2008, van Zandbergen et al., 2010). Second, in populations of unicellular organisms, it is proposed that PCD can limit the spread of infection by viruses (Hazan and Engelberg-Kulka, 2004, Vardi et al., 2012, Vardi et al., 2009). Third, PCD has been documented as playing a critical developmental role in group and multicellular-like behavior (Bayles, 2007, Bayles, 2014, Cornillon et al., 1994, Engelberg-Kulka et al., 2006). Fourth, PCD can be a way of sharing resources during times of nutrient depletion (Bar-Zeev et al., 2013, Franklin et al., 2006). Fifth, in response to physiological stress (nutrient depletion as well as other environmental stressors), populations may regulate their own growth by release of infochemicals (Yordanova et al., 2013, Zuo et al., 2012). Whether or not these proposed mechanisms can find supporting evidence to raise them above "naïve group selection" thinking (Williams, 1966) is the important consideration. 
What are the proposed evolutionary explanations for the benefits associated with apoptosislike PCD?

The explanations for apoptosis-like PCD being selected for are "based on the concept that unicellular life could be able to organize itself into cooperating groups" (Zuppini et al., 2007). Some of the earliest indications that apoptosis-like death can positively impact others in the group came from the model unicellular eukaryote Saccharomyces cerevisiae (Fabrizio et al., 2004, Herker et al., 2004) and the prokaryote Escherichia coli (Hazan and EngelbergKulka, 2004). In S. cerevisiae "old yeast cultures [with features of apoptosis] release substances into the medium that stimulate survival of other old cells" (Herker et al., 2004), and "premature apoptotic death promotes the regrowth of a subpopulation of better-adapted mutants rather than life span extension in the surviving population" (Fabrizio et al., 2004). These data are curious findings, although on their own, are insufficient to demonstrate adaptation. Aging and apoptosis were not differentiated, and the levels-of-selection issue was not clear.

Hazan and Engelberg-Kulka invoke the "characteristics of multicellular organisms" in bacterial cultures to demonstrate that the costs of death at the individual cell level can be offset by selection between populations (Hazan and Engelberg-Kulka, 2004). The levels-ofselection issue was again not explicit, although the argument was that the TA mechanism for death in these experiments was a form of PCD, which benefited the group (Hazan and Engelberg-Kulka, 2004, Hazan et al., 2004). As discussed above, however, Ramisetty and others dispute this (Ramisetty et al., 2015, Ramisetty and Santhosh, 2017) and Ameisen interprets TA mechanisms as addiction molecules without the need to invoke higher levels of selection (Ameisen, 2002). 
Has the direct fitness impact on others in the population been compared for PCD and incidental death or no death?

The fitness effects on others by apoptosis-like PCD have been compared to those due to cellular lysate or no death. In Chlamydomonas reinhardtii, "how an organism dies affects the fitness of its neighbors" (Durand et al., 2011). Others in the population produced more offspring when exposed to the supernatant of cells dying by apoptosis-like PCD compared to the supernatant of healthy cells. Cell lysate was harmful. Similar benefits of apoptosis-like PCD were demonstrated in Dunaliella salina (Orellana et al., 2013) and again in $C$. reinhardtii cells following induction of apoptosis-like PCD by the toxic anti-metabolite mastoparan (Yordanova et al., 2013). Population-level fitness differences are also associated with apoptosis-like death in Leishmania major (van Zandbergen et al., 2006). The entire population lost viability if it was depleted of apoptotic forms, indicating that "apoptotic promastigotes, in an altruistic way, enable the intracellular survival of the viable parasites" (van Zandbergen et al., 2006). These data showed that apoptosis-like death provides a fitness advantage to kin when compared to incidental death or no death.

\section{Can PCD be explained by kin or group selection?}

The individuals in the populations of Chlamydomonas (Durand et al., 2011, Yordanova et al., 2013), and Dunaliella (Orellana et al., 2013) were clonal relatives. In these instances, the theory of kin selection (Michod, 1982, Gardner et al., 2011) suggests that the PCD trait is selected for, since costly individual behaviors will evolve if the cost/benefit ratio is less than the degree of relatedness (Hamilton, 1964a, Hamilton, 1964b). In addition, in $C$. reinhardtii apoptosis-like PCD is negatively allelopathic at the species level (Durand et al., 2014). Kin selection explains the data in the Chlamydomonas and Dunaliella experiments. In some instances, however, when the relationships between individuals are not clonal, it is not 
clear whether the PCD trait has been selected for. In the Saccharomyces experiments (Fabrizio et al., 2004, Herker et al., 2004), for example, it was a mutant subpopulation that benefited preferentially from PCD (Fabrizio et al., 2004).

Some of the most direct evidence that PCD is selected for comes from the group selection experiments using E. coli, where one population with PCD outcompeted one without (Refardt et al., 2013). This occurred even when the group did not comprise clonal relatives. Kin selection and group selection can be considered functional equivalents (Lehmann et al., 2007, Marshall, 2011), but they are causally not the same (detailing the causal representations of the different process is beyond the scope of this paper and the reader is referred elsewhere, see Okasha, 2016). It seems therefore, that both kin and group selection are required to explain situations where it is demonstrated that PCD is selected for.

Are there any in vivo or field data on PCD?

It has been suggested that "laboratory microorganisms that have been cultured for long periods under optimized conditions might differ markedly from those that exist in natural ecosystems" (Palkova, 2004). It is true that many of the model organisms used in the above experiments have been in long-term laboratory culture, such as the Chlamydomonas and Saccharomyces isolates. However, the phytoplankton-archaeon system (Orellana et al., 2013) was isolated from the Great Salt Lake, United States, and the experimental results in Saccharomyces were confirmed in yeast cells from organically grown Californian red grapes (Fabrizio et al., 2004). In addition, the dinoflagellate Peridinium gatunense used to study PCD synchronization in populations was isolated from Lake Kinneret, Israel (Vardi et al., 2007). The L. major studies were conducted in vitro and in vivo (van Zandbergen et al., 2006). Given these findings, it seems reasonable to assume that the data from the fitness experiments above are applicable to natural settings. 
What can be concluded from the answers to the above questions?

In some instances, at least, PCD has a positive effect on group fitness and the PCD character itself has been selected for. Apparent PCD is not always pleiotropic and the null hypothesis that PCD is a neutral event is falsified.

\section{PCD as an Adaptation for Death}

We argued above that what distinguishes true PCD from other forms of death is that in true PCD death itself has been selected for-it is not a mere by-product of selection for other adaptations. When PCD-like death is not an adaptation, when it is secondary to another adaptation (death from autophagy, for example), or when it is a by-product pleiotropically linked to some other essential function, such death should be considered ersatz PCD, not true PCD (Table 2, Figure 1). Because this distinction is based on an adaptation for death, we must consider how such an adaptation can come about

In considering whether a trait is an adaptation, we should distinguish between traits that are adaptive (have a current fitness benefit) from those that are an adaptation (are due to an evolutionary response to past selection for the trait) (van Valen, 2009). Thus, we must distinguish PCD being adaptive (there are group-level benefits that may themselves not be the result of adaptation), from it being an adaptation (where the fitness effects of PCD on others in the population have been selected for, and there has been an evolutionary response to this selection).

The central question concerning PCD as a group-level adaptation is the relationship between the PCD trait and the fitness of groups of cells that manifest the trait. How should this relationship between PCD and selection be formulated to include the full range of the PCD trait (or character) discussed above? Okasha phrases the issue more generally and asks 
the question, "when is a character-fitness covariance indicative of direct selection at the level in question, and when is it a by-product of selection at another level?" (Okasha, 2006). We will use the Price equation to examine this question.

\section{The Price Formalism and PCD}

The Price equation (Price, 1972, Price, 1995) has been used extensively to examine the levels-of-selection problem as it applies to a range of questions in evolution (Damuth and Heisler, 1988, Frank, 1998, Michod, 1999, Queller, 1992, Sober and Wilson, 1998). Here we use the Price formalism adopted by Okasha (Okasha, 2006) for MLS1 (multilevel selection type 1) to examine the levels-of-selection problem in PCD. Our rationale is that the experimental designs that tested for group-level effects are appropriate for MLS1 (groups are aggregates of individuals and the individuals are the focal units) as opposed to MLS2 (where the group is the focal unit). The reduced version of the Price equation is

$$
\bar{w} \Delta \bar{z}=\operatorname{Cov}\left(w_{i}, z_{i}\right)
$$

where $\bar{W}$ is the average individual fitness, $\Delta \bar{z}$ is the change in the average of the character trait (in this case PCD) from one generation to the next and $\operatorname{Cov}\left(w_{i}, z_{i}\right)$ is the covariance between fitness and character trait for the $\mathrm{i}^{\text {th }}$ individual. The overall character-fitness covariance of the entire population comprises two parts: the covariance between groups and the average (or expected) covariance within groups

$$
\operatorname{Cov}\left(w_{i}, z_{i}\right)=\operatorname{Cov}(W, Z)+E(\operatorname{Cov}(w, z))
$$

which allows us to rewrite the product of the average fitness and average change in character trait of the population as 


$$
\bar{w} \Delta \bar{z}=\operatorname{Cov}(W, Z)+E(\operatorname{Cov}(w, z))
$$

For any individual, the mean fitness and the change in the mean of the character depend on the covariance at the level of the group (first term) and at the level of individuals in the group (second term). The question of PCD as a group-level adaptation hinges on knowing whether both terms in the Price equation are necessary to explain the observed data. In other words, can $\bar{w} \Delta \bar{z}$ be explained by the second term alone (covariance at the level of the individual cell), or is the first term (covariance at the group level) also required to explain the empirical observations?

There are two points worth noting before interpreting the empirical data with Eq. 3. First, we assume there is no transmission bias in PCD and that the trait is transmitted faithfully from parent to offspring and the evolutionary change is due to natural selection alone. We acknowledge that this does not separate fitness effects from transmission bias, should there be any. There are different decompositions of the equation that deal adequately with this separation (Luque, 2017), however, these include additional terms for which there are no empirical data. More importantly, the assumption of no transmission bias is actually a worst-case scenario, because individuals with the PCD trait die or have lower viability or reproductive potential. If there is any transmission bias at the individual level, it diminishes the evolutionary response to natural selection rather than enhancing it, since the trait is not passed faithfully from parent to offspring. Second, it should also be remembered that the character " $z$ " in question, PCD, is treated as a continuous trait (see above). The loss of viability is graded and non-discrete. At one end PCD may simply be a transient hiatus in cell cycle progression. At the other end of the scale there is the immediate implementation of the genetic program for death. Between these two extremes there are "degrees of death" like prolonged arrest in the cell cycle, senescence or some other loss of viability, encystation and spore formation, and degrees of autophagy. 
The experiments with E. coli (Refardt et al., 2013), L. major (van Zandbergen et al., 2006), D. salina (Orellana et al., 2013) and C. reinhardtii (Durand et al., 2014, Durand et al., 2011) are some of those that are accessible for interpretation with the Price equation. Calculating the covariance was not the aim in these experiments, but what is clear from the data, and indeed intuitively obvious, is that fitness and PCD have an inverse relationship. As the PCD pathway is implemented, the cell gradually dies and fitness decreases. The second term in Eq. 3, $E(\operatorname{Cov}(w, z))$, is negative. The experimental results showed that in cultures where PCD occurred, the remaining individuals produced more offspring. In Eq. 3, the lefthand side is positive since the change in $\operatorname{PCD}(\Delta \bar{z})$ (this was measured directly in the $E$. coli experiments) is positive. The second term on the right-hand side, the individual characterfitness covariance, is negative. We can conclude, therefore, that the term $\operatorname{Cov}(W, Z)$ must be positive.

Interpreting the empirical data with the Price equation, thus reveals that at the group level PCD and fitness covary positively. In other words, there is selection at the group level.

\section{Group-Level Effects, PCD, and the Many Meanings of "Adaptation"}

The experimental data for PCD in unicellular organisms and an interpretation with the Price equation provide evidence that apoptosis-like PCD in L. major (van Zandbergen et al., 2006), D. salina (Orellana et al., 2013), C. reinhardtii (Durand et al., 2014, Durand et al., 2011) and phage-induced PCD in E. coli (Refardt et al., 2013) enhance fitness at a group level, and thus that this is selected for. As Refardt et al. state, PCD is an "altruism [that] can evolve, even when relatedness is low." Can we conclude that the character is therefore an adaptation, which will justify the usage of this term in our definition? A review of the debates over how to understand adaptation is beyond the scope of this article and the reader is referred elsewhere (Gardner, 2017, Gould and Lewontin, 1979, Gould and Lloyd, 1999, Gould and 
Vrba, 1982, Hendry and Gonzalez, 2008, Reeve and Sherman, 1993, Rose and Lauder, 1996, Sansom, 2003, van Valen, 2009, Williams, 1966). But to clarify its inclusion in our definition, it is necessary to state our own understanding of the term.

Some biologists argue for an ahistorical conception of adaptation, in which an increase in fitness causally related to a character is sufficient to infer that the character is an adaptation (Reeve and Sherman, 1993). In a sense, this is saying that the trait is currently adaptive (as opposed to it being an adaptation), and the PCD data above easily pass this evaluation. The received view, however, is that a trait is an adaptation only if it has a particular evolutionary history (van Valen, 2009).This evolutionary history, as Williams argues, must involve the trait exhibiting a demonstrable fit to some function (Williams, 1966). In this case, there are less empirical data. The experiments in E. coli, however, do fulfill this more stringent criterion, since the abortive infection system (Abi) is demonstrably tied to cell death (Refardt et al., 2013). There is also no other cellular function associated with any of the molecular components leading to PCD. In the experiments using L. major, $C$. reinhardtii, and D. salina, this criterion for adaptation was not specifically investigated.

\section{Conclusion}

In this essay, we have examined the different definitions and meanings of PCD. Mechanistic definitions have hindered attempts to understand the meaning and evolutionary ecology of PCD. The same mechanism may be adaptive in one organism, but a neutral or deleterious result of pleiotropy in another. Instead, we propose an evolutionary definition of PCD that is agnostic of the cellular mechanisms. This definition takes into account the evolutionary history of the trait with respect to its function and the selective history of that function. We claim that the definition of PCD as an adaptation to abiotic or biotic environmental stresses resulting in the death of the cell is justified. However, we acknowledge that, to date, there 
have been only a few experiments performed that included all of the most stringent criteria for labeling a trait an adaptation.

We conclude that true PCD is an adaptation resulting from group-level selection, although what exactly the group is will depend on the ecological context. It may comprise kin (Michod, 1982, Gardner et al., 2011), genetically unrelated individuals (Sober and Wilson, 1994), or even holobionts (Roughgarden et al., 2017) in the case of phytoplankton and their associated microbiome. In instances where what appears to be PCD has itself not been selected for, but is the result of nonadaptive processes, this is ersatz PCD, not true PCD. We hope that this way of distinguishing PCD from related phenomena will help to resolve disputes concerning the evolution of microbial cell death and benefit future empirical studies. 
Table 1 The many meanings of programmed cell death in unicellular organisms

Mortality in unicellular organisms is a poorly defined concept. The references listed here provide a range of the different terms, definitions, interpretations, or contexts employed.

\begin{tabular}{|c|c|c|}
\hline $\operatorname{Term}(\mathbf{s})$ & Definition, interpretation, or context & Reference(s) \\
\hline $\begin{array}{l}\text { Self- } \\
\text { destruction, } \\
\text { physiological } \\
\text { cell death, } \\
\text { PCD }\end{array}$ & $\begin{array}{l}\text { There is "no such thing as a bona fide genetic death } \\
\text { program in cells." }\end{array}$ & (Ameisen, 2002) \\
\hline $\begin{array}{l}\text { Cell death } \\
\text { program } \\
\text { (CDP) }\end{array}$ & $\begin{array}{l}\text { In CDP "the cell is the system whose constitutive } \\
\text { elements are its own genes and proteins which are } \\
\text { involved in the molecular mechanisms of cell death." }\end{array}$ & $\begin{array}{l}\text { (Ratel et al., } \\
\text { 2001) }\end{array}$ \\
\hline $\begin{array}{l}\text { Active cell } \\
\text { death }(\mathrm{ACD})\end{array}$ & $\begin{array}{l}\text { ACD is "any cell death process that is genetically } \\
\text { determined, energy dependent, and proceeds through } \\
\text { a series of organized steps." }\end{array}$ & $\begin{array}{l}\text { (Nedelcu et al., } \\
\text { 2011) }\end{array}$ \\
\hline $\begin{array}{l}\text { Chronological } \\
\text { aging or } \\
\text { apoptosis }\end{array}$ & $\begin{array}{l}\text { "Apoptosis is a form of cellular suicide that leads to } \\
\text { the rapid removal of unwanted or damaged cells." }\end{array}$ & $\begin{array}{l}\text { (Fabrizio et al., } \\
\text { 2004, Herker et } \\
\text { al., 2004) }\end{array}$ \\
\hline $\begin{array}{l}\text { Programmed } \\
\text { organismal } \\
\text { death (POD) }\end{array}$ & $\begin{array}{l}\text { POD is "organismal death that results directly from } \\
\text { an active process that is internally controlled and } \\
\text { regulated by the organism." }\end{array}$ & $\begin{array}{l}\text { (Pepper et al., } \\
\text { 2013) }\end{array}$ \\
\hline PCD & $\begin{array}{l}\text { PCD is "cell death resulting from gene expression } \\
\text { within the moribund cell." }\end{array}$ & $\begin{array}{l}\text { (Franklin et al., } \\
\text { 2006) }\end{array}$ \\
\hline
\end{tabular}




\begin{tabular}{|c|c|c|}
\hline $\begin{array}{l}\text { Abortive } \\
\text { infection } \\
\text { system (Abi), } \\
\text { altruistic } \\
\text { death }\end{array}$ & $\begin{array}{l}\text { "The Abi system could reflect an altruistic act that } \\
\text { allows infected bacteria to commit suicide in order to } \\
\text { prevent parasite transmission to nearby relatives." }\end{array}$ & $\begin{array}{l}\text { (Refardt et al., } \\
\text { 2013) }\end{array}$ \\
\hline $\begin{array}{l}\text { mazEF- } \\
\text { mediated cell } \\
\text { death }\end{array}$ & $\begin{array}{l}m a z E F \text { action causes individual cells to die by "a } \\
\text { regulatable chromosomal toxin-antitoxin module." }\end{array}$ & $\begin{array}{l}\text { (Hazan and } \\
\text { Engelberg- } \\
\text { Kulka, 2004) }\end{array}$ \\
\hline $\begin{array}{l}\text { Autophagy } \\
\text { morphotype }\end{array}$ & $\begin{array}{l}\text { An explicit definition is not provided, rather the } \\
\text { features of the autophagy morphotype are described. }\end{array}$ & $\begin{array}{l}\text { (Jiménez et al., } \\
\text { 2009) }\end{array}$ \\
\hline PCD & $\begin{array}{l}\text { PCD "confers a selective advantage to a population } \\
\text { during subsequent seasons." }\end{array}$ & $\begin{array}{l}\text { (Vardi et al., } \\
\text { 1999) }\end{array}$ \\
\hline
\end{tabular}




\section{Table 2 Evolutionary definitions of death in unicellular organisms}

Three different kinds of death are defined in this article: (1) $P C D$ is an adaptation to abiotic or biotic environmental stresses resulting in the death of the cell; (2) ersatz PCD is also intrinsic to the cell, but the death phenotype itself has not been selected for (examples include pleiotropy, genetic drift, and trade-offs); (3) incidental death is death due to causes extrinsic to the cell, for example through physicochemical damage. The evolutionary definitions are not based on specific biochemical mechanisms. The same taxon may exhibit PCD and ersatz PCD. For example, PCD in E. coli is an adaptation to viral invasion, and ersatz PCD occurs in $E$. coli as a side effect of the mazEF addition module. Similarly, the same mechanism can have different evolutionary histories. Autophagy, for example, is adaptive in $D$. discoideum because of the developmental stage of forming stalk structures. However, the same mechanism appears to be pleiotropic in D. viridis. The phenomenon of aging is intentionally excluded since it is itself a source of much debate without consensus for an evolutionary definition. Aging is, however, different from the three kinds of death defined here (see text).

\begin{tabular}{|c|c|c|}
\hline $\begin{array}{l}\text { Types of death in } \\
\text { unicellular } \\
\text { organisms }\end{array}$ & $\begin{array}{l}\text { Evolutionary } \\
\text { definition }\end{array}$ & Examples \\
\hline PCD & $\begin{array}{l}\text { PCD is an } \\
\text { adaptation to } \\
\text { abiotic or biotic } \\
\text { environmental } \\
\text { stresses resulting in } \\
\text { the death of the } \\
\text { cell. }\end{array}$ & $\begin{array}{l}\text { E. coli (Refardt et al., 2013) } \\
\text { C. reinhardtii (Durand et al., 2014, Durand } \\
\text { et al., 2011, Durand et al., 2016, } \\
\text { Yordanova et al., 2013) } \\
\text { D. salina (Orellana et al., 2013) }\end{array}$ \\
\hline
\end{tabular}




\begin{tabular}{|c|c|c|}
\hline & & $\begin{array}{l}\text { D. discoideum (Cornillon et al., 1994, Lam } \\
\text { et al., 2007, Luciani et al., 2017, Olie et al., } \\
\text { 1998) } \\
\text { L. major (van Zandbergen et al., 2006, van } \\
\text { Zandbergen et al., 2010) }\end{array}$ \\
\hline Ersatz PCD & $\begin{array}{l}\text { Ersatz PCD is } \\
\text { intrinsic to the cell } \\
\text { but the trait itself } \\
\text { has not been } \\
\text { selected for death. }\end{array}$ & $\begin{array}{l}\text { E. coli (Hazan and Engelberg-Kulka, 2004, } \\
\text { Hazan et al., 2004) } \\
\text { D. viridis (Jiménez et al., 2009) } \\
\text { D. tertiolecta (Segovia et al., 2003) }\end{array}$ \\
\hline Incidental death & $\begin{array}{l}\text { Incidental death is } \\
\text { extrinsic to the cell. }\end{array}$ & Any organism \\
\hline
\end{tabular}




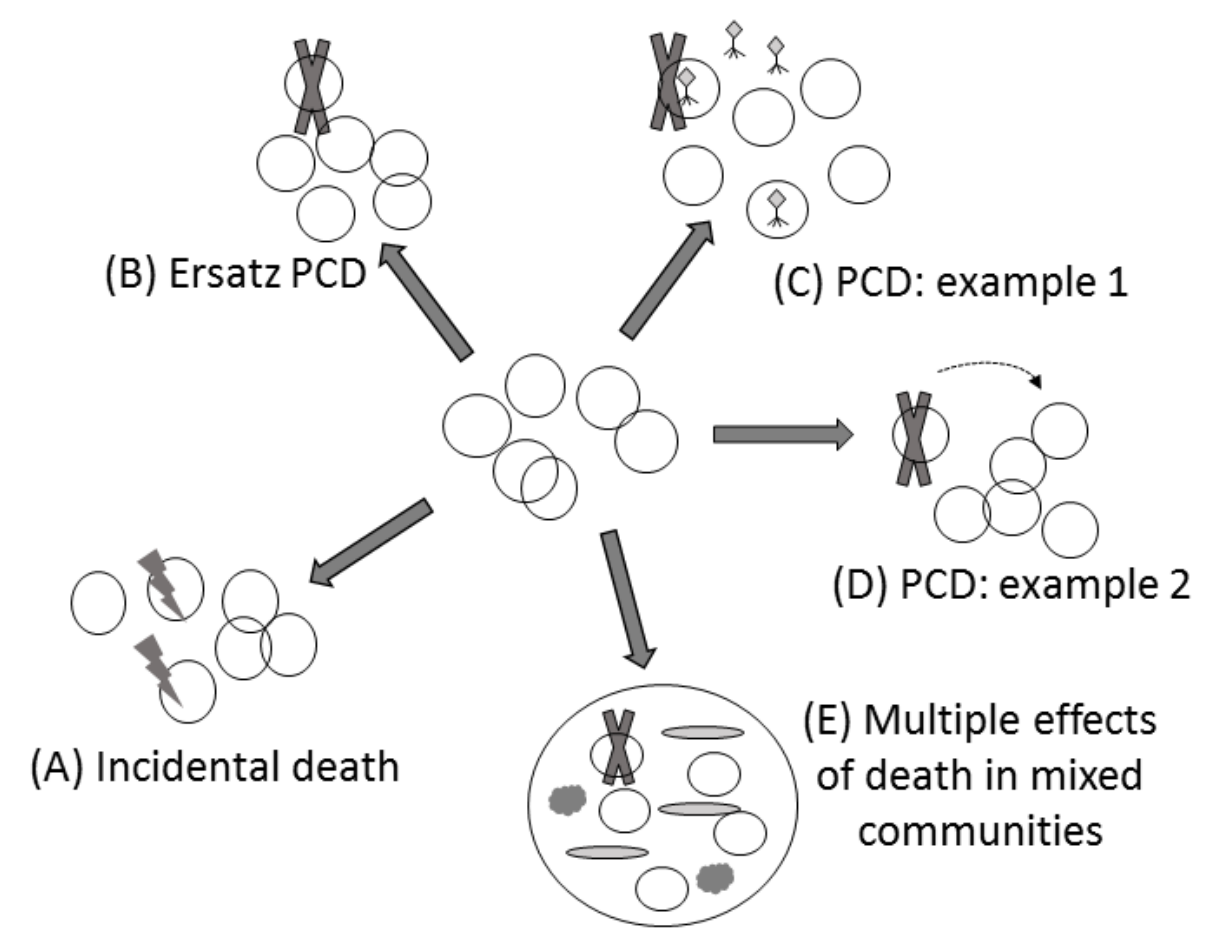

Fig 1 The evolution of death in unicellular organisms

Mortality in a population of healthy cells may take the following forms. (A) Incidental death, in which cells can be damaged by physical or chemical means and die from extrinsic insults. As a result, cellular contents are liberated into the external microenvironment and may harm others. (B) Ersatz PCD, in which the cell death phenotype is the result of internal cues, but the mechanism involved is not an adaptation for this death. (C, D) $P C D$, in which the phenotype is an adaptation for death and evolves by kin/group selection. The mechanisms may vary and two examples are illustrated. In (C), PCD limits or aborts the spread of viruses through the population (Refardt et al., 2013, Vardi et al., 2012).(Refardt et al., 2013, Vardi et al., 2012) In (D), the fitness advantages are provided by nutritional resources or chemical signals. In (E), microbial communities comprising different taxa may exhibit multiple kinds of death (incidental, ersatz PCD and PCD) with multiple downstream effects in the community 


\section{Acknowledgments}

PMD is supported by grants from the National Research Foundation (South Africa) and the

Centre of Excellence for Palaeosciences. We thank Andrew Ndhlovu, Victor Luque, and two anonymous reviewers for helpful comments that improved this manuscript significantly.

\section{References}

AFFENZELLER, M. J., DAREHSHOURI, A., ANDOSCH, A., LUTZ, C. \& LUTZ-MEINDL, U. 2009. PCD and autophagy in the unicellular green alga Micrasterias denticulata. Autophagy, 5, 854-5.

AL-OLAYAN, E. M., WILLIAMS, G. T. \& HURD, H. 2002. Apoptosis in the malaria protozoan, Plasmodium berghei: a possible mechanism for limiting intensity of infection in the mosquito. Int J Parasitol, 32, 1133-43.

AMEISEN, J. C. 1996. The origin of programmed cell death. Science, 272, 1278-9.

AMEISEN, J. C. 2002. On the origin, evolution, and nature of programmed cell death: a timeline of four billion years. Cell Death Differ, 9, 367-93.

ARAVIND, L., DIXIT, V. M. \& KOONIN, E. V. 1999. The domains of death: evolution of the apoptosis machinery. Trends Biochem Sci, 24, 47-53.

BAR-ZEEV, E., AVISHAY, I., BIDLE, K. D. \& BERMAN-FRANK, I. 2013. Programmed cell death in the marine cyanobacterium Trichodesmium mediates carbon and nitrogen export. ISME J, 7, 2340-8.

BAYLES, K. W. 2007. The biological role of death and lysis in biofilm development. Nat Rev Microbiol, 5, 721-6.

BAYLES, K. W. 2014. Bacterial programmed cell death: making sense of a paradox. Nat Rev Microbiol, $12,63-9$.

BERGES, J. A. \& CHOI, C. J. 2014. Cell death in algae: physiological processes and relationships with stress. Perspectives in phycology, 1, 103-112.

BERGES, J. A. \& FALKOWSKI, P. G. 1998. Physiological stress and cell death in marine phytoplankton: Induction of proteases in response to nitrogen or light limitation. Limnology and Oceanography, 43, 129-135.

BERMAN-FRANK, I., BIDLE, K. D., HARAMATY, L. \& FALKOWSKI, P. G. 2004. The demise of the marine cyanobacterium, Trichodesmium spp., via an autocatalyzed cell death pathway. Limnology and Oceanography, 49, 997-1005.

BIDLE, K. D. 2015. The Molecular Ecophysiology of Programmed Cell Death in Marine Phytoplankton. Annual review of marine science, 7, 341-375.

BIDLE, K. D. 2016. Programmed Cell Death in Unicellular Phytoplankton. Curr Biol, 26, R594-607.

BONNER, J. T. 2013. Randomness in Evolution, Princeton, Princeton university press.

CARMONA-GUTIERREZ, D., BAUER, M. A., ZIMMERMANN, A., AGUILERA, A., AUSTRIACO, N., AYSCOUGH, K., BALZAN, R., BAR-NUN, S., BARRIENTOS, A., BELENKY, P., BLONDEL, M., BRAUN, R. J., BREITENBACH, M., BURHANS, W. C., BUTTNER, S., CAVALIERI, D., CHANG, M., COOPER, K. F., CORTE-REAL, M., COSTA, V., CULLIN, C., DAWES, I., DENGJEL, J., DICKMAN, M. B., EISENBERG, T., FAHRENKROG, B., FASEL, N., FROHLICH, K. U., GARGOURI, A., GIANNATTASIO, S., GOFFRINI, P., GOURLAY, C. W., GRANT, C. M., GREENWOOD, M. T., GUARAGNELLA, N., HEGER, T., HEINISCH, J., HERKER, E., HERRMANN, J. M., HOFER, S., JIMENEZ-RUIZ, A., JUNGWIRTH, H., KAINZ, K., KONTOYIANNIS, D. P., LUDOVICO, P., MANON, 
S., MARTEGANI, E., MAZZONI, C., MEGENEY, L. A., MEISINGER, C., NIELSEN, J., NYSTROM, T., OSIEWACZ, H. D., OUTEIRO, T. F., PARK, H. O., PENDL, T., PETRANOVIC, D., PICOT, S., POLCIC, P., POWERS, T., RAMSDALE, M., RINNERTHALER, M., ROCKENFELLER, P., RUCKENSTUHL, C., SCHAFFRATH, R., SEGOVIA, M., SEVERIN, F. F., SHARON, A., SIGRIST, S. J., SOMMER-RUCK, C., SOUSA, M. J., THEVELEIN, J. M., THEVISSEN, K., TITORENKO, V., TOLEDANO, M. B., TUITE, M., VOGTLE, F. N., WESTERMANN, B., WINDERICKX, J., WISSING, S., WOLFL, S., ZHANG, Z. J., ZHAO, R. Y., ZHOU, B., GALLUZZI, L., KROEMER, G. \& MADEO, F. 2018. Guidelines and recommendations on yeast cell death nomenclature. Microb Cell, 5, 4-31.

COLLIN, R. 1906. Recherches cytologiques sur le développment de la cellule nerveuse. Névrae, 8, 181-308.

CORNILLON, S., FOA, C., DAVOUST, J., BUONAVISTA, N., GROSS, J. D. \& GOLSTEIN, P. 1994. Programmed cell death in Dictyostelium. J Cell Sci, 107 ( Pt 10), 2691-704.

DAMUTH, J. \& HEISLER, I. L. 1988. Alternative formulations of of multi-level selection. Biology and Philosophy, 3, 407-430.

DEBRABANT, A. \& NAKHASI, H. 2003. Programmed cell death in trypanosomatids: is it an altruistic mechanism for survival of the fittest? Kinetoplastid Biol Dis, 2, 7.

DEPONTE, M. 2008. Programmed cell death in protists. Biochim Biophys Acta, 1783, 1396-405.

DURAND, P. M., CHOUDHURY, R., RASHIDI, A. \& MICHOD, R. E. 2014. Programmed death in a unicellular organism has species-specific fitness effects. Biol Lett, 10, 20131088.

DURAND, P. M. \& COETZER, T. L. 2008. Utility of computational methods to identify the apoptosis machinery in unicellular eukaryotes. Bioinform Biol Insights, 2, 101-17.

DURAND, P. M., RASHIDI, A. \& MICHOD, R. E. 2011. How an organism dies affects the fitness of its neighbors. Am Nat, 177, 224-32.

DURAND, P. M., SYM, S. \& MICHOD, R. E. 2016. Programmed Cell Death and Complexity in Microbial Systems. Curr Biol, 26, R587-93.

ENGELBERG-KULKA, H., AMITAI, S., KOLODKIN-GAL, I. \& HAZAN, R. 2006. Bacterial programmed cell death and multicellular behavior in bacteria. PLoS Genet, 2, e135.

ENGELBRECHT, D. \& COETZER, T. L. 2013. Turning up the heat: heat stress induces markers of programmed cell death in Plasmodium falciparum in vitro. Cell Death Dis, 4, e971.

ERNST, M. 1926. Über Untergang von Zellen während der normalen Entwicklung bei Wirbeltieren. $Z$ Anat Entwicklungsgesch, 79, 228-262.

FABRIZIO, P., BATTISTELLA, L., VARDAVAS, R., GATTAZZO, C., LIOU, L. L., DIASPRO, A., DOSSEN, J. W., GRALLA, E. B. \& LONGO, V. D. 2004. Superoxide is a mediator of an altruistic aging program in Saccharomyces cerevisiae. J Cell Biol, 166, 1055-67.

FISHER, R. M., CORNWALLIS, C. K. \& WEST, S. A. 2013. Group formation, relatedness, and the evolution of multicellularity. Curr Biol, 23, 1120-5.

FRADE, J. M. \& MICHAELIDIS, T. M. 1997. Origin of eukaryotic programmed cell death: a consequence of aerobic metabolism? Bioessays, 19, 827-32.

FRANK, S. A. 1998. Foundations of social evolution, Princeton, Princeton university press.

FRANKLIN, D. J., BRUSSARD, C. P. D. \& BERGES, J. A. 2006. What is the nature and role of programmed cell death in phytoplankton ecology? European Journal of Phycology, 41, 1-14.

FRANKLIN, L. R. 2007. Bacreria, sex and systematics. Philosophy of Science, 74, 69-95.

GARDNER, A. 2017. The purpose of adaptation. Interface Focus, 7, 20170005.

GARDNER, A. \& KUMMERLI, R. 2008. Social evolution: this microbe will self-destruct. Curr Biol, 18, R1021-3.

GARDNER, A., WEST, S. A. \& WILD, G. 2011. The genetical theory of kin selection. J Evol Biol, 24, 1020-43.

GLÜCKSMANN, A. 1951. Cell deaths in normal vertebrate ontogeny. Biol Rev Camb Philos Soc, 26, 5986.

GOULD, S. J. \& LEWONTIN, R. C. 1979. The spandrels of San Marco and the Panglossian paradigm: a critique of the adaptationist programme. Proc R Soc Lond B Biol Sci, 205, 581-98. 
GOULD, S. J. \& LLOYD, E. A. 1999. Individuality and adaptation across levels of selection: how shall we name and generalize the unit of Darwinism? Proc Natl Acad Sci U S A, 96, 11904-9.

GOULD, S. J. \& VRBA, E. S. 1982. Exaptation-a missing term in the sience of form. Paleobiology, 8, 415.

HAMBURGER, V. \& LEVI-MONTALCINI, R. 1949. Proliferation, differentiation and degeneration in the spinal ganglia of the chick embryo under normal and experimental conditions. Journal of experimental zoology, 111, 457-501.

HAMILTON, W. D. 1964a. The genetical evolution of social behaviour. I. Journal of theoretical biology, 7, 1-16.

HAMILTON, W. D. 1964b. The genetical evolution of social behaviour. II. Journal of theoretical biology, 7, 17-52.

HANSCHEN, E., DAVISON, D. R., GROCHAU-WRIGHT, Z. \& MICHOD, R. E. 2018. Individuality and the major evolutionary transitions. In: GISSIS, S., LAMM, E. \& SHAVIT, A. (eds.) In: Landscapes of Collectivity in the Life Sciences. Boston, Mass.: MIT Press.

HAZAN, R. \& ENGELBERG-KULKA, H. 2004. Escherichia coli mazEF-mediated cell death as a defense mechanism that inhibits the spread of phage P1. Mol Genet Genomics, 272, 227-34.

HAZAN, R., SAT, B. \& ENGELBERG-KULKA, H. 2004. Escherichia coli mazEF-mediated cell death is triggered by various stressful conditions. J Bacteriol, 186, 3663-9.

HENDRY, A. P. \& GONZALEZ, A. 2008. Whither adaptation? Biology and Philosophy, 23, 673-699.

HERKER, E., JUNGWIRTH, H., LEHMANN, K. A., MALDENER, C., FROHLICH, K. U., WISSING, S., BUTTNER, S., FEHR, M., SIGRIST, S. \& MADEO, F. 2004. Chronological aging leads to apoptosis in yeast. J Cell Biol, 164, 501-7.

IRANZO, J., LOBKOVSKY, A. E., WOLF, Y. I. \& KOONIN, E. V. 2014. Virus-host arms race at the joint origin of multicellularity and programmed cell death. Cell Cycle, 13, 3083-8.

JIMÉNEZ, C., CAPASSO, J. M., EDELSTEIN, C. L., RIVARD, C. J., LUCIA, S., BREUSEGEM, S., BERL, T. \& SEGOVIA, M. 2009. Different ways to die: cell death modes of the unicellular chlorophyte Dunaliella viridis exposed to various environmental stresses are mediated by the caspaselike activity DEVDase. J Exp Bot, 60, 815-28.

KACZANOWSKI, S., SAJID, M. \& REECE, S. E. 2011. Evolution of apoptosis-like programmed cell death in unicellular protozoan parasites. Parasit Vectors, 4, 44.

KALLIUS, E. 1931. Der Zelluntergang als Mechanismus bei der Histio-and Morphogenese. Verh Anat Ges Suppl Anat Anz, 72, 10-22.

KAPSETAKI, S. E., TEP, A. \& WEST, S. A. 2017. How do algae form multicellular groups? Evol Ecol Res, $18,663-675$.

KASUBA, K. C., VAVILALA, S. L. \& D'SOUZA, J. S. 2015. Apoptosis-like cell death in photosynthetic unicellular organisms - a review. Algal research, 12, 126-133.

KERR, J. F., WYLLIE, A. H. \& CURRIE, A. R. 1972. Apoptosis: a basic biological phenomenon with wideranging implications in tissue kinetics. British journal of cancer, 26, 239.

KHAN, N. A., IQBAL, J. \& SIDDIQUI, R. 2015. Stress management in cyst-forming free-living protists: programmed cell death and/or encystment. Biomed Res Int, 2015, 437534.

KIEL, J. A. 2010. Autophagy in unicellular eukaryotes. Philos Trans $R$ Soc Lond B Biol Sci, 365, 819-30.

KLIM, J., GLADKI, A., KUCHARCZYK, R., ZIELENKIEWICZ, U. \& KACZANOWSKI, S. 2018. Ancestral State Reconstruction of the Apoptosis Machinery in the Common Ancestor of Eukaryotes. G3 (Bethesda), 8, 2121-2134.

KOONIN, E. \& ARAVIND, L. 2002. Origin and evolution of eukaryotic apoptosis: the bacterial connection. Cell death and differentiation, 9, 394-404.

KOONIN, E. V. 2011. The Logic of Chance: The Nature and Origin of Biological Evolution, Upper Saddle River, FT Press.

KOONIN, E. V. 2016. Splendor and misery of adaptation, or the importance of neutral null for understanding evolution. BMC Biol, 14, 114. 
KROEMER, G., GALLUZZI, L., VANDENABEELE, P., ABRAMS, J., ALNEMRI, E. S., BAEHRECKE, E. H., BLAGOSKLONNY, M. V., EL-DEIRY, W. S., GOLSTEIN, P., GREEN, D. R., HENGARTNER, M., KNIGHT, R. A., KUMAR, S., LIPTON, S. A., MALORNI, W., NUNEZ, G., PETER, M. E., TSCHOPP, J., YUAN, J., PIACENTINI, M., ZHIVOTOVSKY, B., MELINO, G. \& NOMENCLATURE COMMITTEE ON CELL, D. 2009. Classification of cell death: recommendations of the Nomenclature Committee on Cell Death 2009. Cell Death Differ, 16, 3-11.

LAM, D., LEVRAUD, J. P., LUCIANI, M. F. \& GOLSTEIN, P. 2007. Autophagic or necrotic cell death in the absence of caspase and bcl-2 family members. Biochem Biophys Res Commun, 363, 53641.

LAUN, P., PICHOVA, A., MADEO, F., FUCHS, J., ELLINGER, A., KOHLWEIN, S., DAWES, I., FROHLICH, K. U. \& BREITENBACH, M. 2001. Aged mother cells of Saccharomyces cerevisiae show markers of oxidative stress and apoptosis. Mol Microbiol, 39, 1166-73.

LEHMANN, L., KELLER, L., WEST, S. \& ROZE, D. 2007. Group selection and kin selection: two concepts but one process. Proc Natl Acad Sci U S A, 104, 6736-9.

LEWIS, K. 2000. Programmed death in bacteria. Microbiol Mol Biol Rev, 64, 503-14.

LOCKSHIN, R. A. \& WILLIAMS, C. M. 1964. Programmed cell death-II. Endocrine potentiation of the breakdown of the intersegmental muscles of silkmoths. Journal of Insect Physiology, 10, 643649.

LUCIANI, M. F., SONG, Y., SAHRANE, A., KOSTA, A. \& GOLSTEIN, P. 2017. Early nucleolar disorganization in Dictyostelium cell death. Cell Death Dis, 8, e2528.

LUQUE, V. 2017. One Equation To Rule Them All: A philosophical analysis of the Price equation. Biology and Philosophy, 32, 97-125.

LYNCH, M. 2007. The frailty of adaptive hypotheses for the origins of organismal complexity. Proc Natl Acad SciU S A, 104 Suppl 1, 8597-604.

MALLET, J. 1995. A species definition for the modern synthesis. Trends Ecol Evol, 10, 294-9.

MARSHALL, J. A. 2011. Group selection and kin selection: formally equivalent approaches. Trends Ecol Evol, 26, 325-32.

MERLO, L. M., PEPPER, J. W., REID, B. J. \& MALEY, C. C. 2006. Cancer as an evolutionary and ecological process. Nat Rev Cancer, 6, 924-35.

MICHOD, R. E. 1982. The theory of kin selection. Annual Review of Ecology and Systematics, 13, 2355.

MICHOD, R. E. 1999. Darwinian dynamics: evolutionary transitions in fitness and individuality, Princeton, Princeton university press.

MICHOD, R. E. 2003. Cooperation and conflict mediation during the origin ofmulticcllularity from genetic and cultural evolution of cooperation. In: (ED.), P. H. (ed.) In: Genetic and Cultural Evolution of Cooperation (pp. 261-307). Cambridge, MA: MIT Press.

MICHOD, R. E. \& ROZE, D. 2001. Cooperation and conflict in the evolution of multicellularity. Heredity, 86, 1-7.

MOHARIKAR, S., D'SOUZA, J. S., KULKARNI, A. B. \& RAO, B. J. 2006. Apoptotic-like cell death pathway is induced in unicellular chlorophyte Chlamydomonas reinhardtii (Chlorophyceae) cells following UV irradiation: detection and functional analyses. Journal of Phycology, 42, 423433.

NEDELCU, A. M. 2009. Comparative genomics of phylogenetically diverse unicellular eukaryotes provide new insights into the genetic basis for the evolution of the programmed cell death machinery. Journal of molecular evolution, 68, 256-268.

NEDELCU, A. M., DRISCOLL, W. W., DURAND, P. M., HERRON, M. D. \& RASHIDI, A. 2011. On the paradigm of altruistic suicide in the unicellular world. Evolution, 65, 3-20.

NEDELCU, A. M. \& MICHOD, R. E. 2003. Sex as a response to oxidative stress: the effect of antioxidants on sexual induction in a facultatively sexual lineage. Proc Biol Sci, $270 \mathrm{Suppl} 2$, S136-9.

OKASHA, S. 2006. Evolution and the levels of selection, Oxford, Oxford University Press. 
OKASHA, S. 2016. The Relation between Kin and Multilevel Selection: An Approach Using Causal Graphs. British Journal for the Philosophy of Science, 67, 435-470.

OLIE, R. A., DURRIEU, F., CORNILLON, S., LOUGHRAN, G., GROSS, J., EARNSHAW, W. C. \& GOLSTEIN, P. 1998. Apparent caspase independence of programmed cell death in Dictyostelium. Curr Biol, 8, 955-8.

ORELLANA, M. V., PANG, W. L., DURAND, P. M., WHITEHEAD, K. \& BALIGA, N. S. 2013. A role for programmed cell death in the microbial loop.

PALKOVA, Z. 2004. Multicellular microorganisms: laboratory versus nature. EMBO Rep, 5, 470-6.

PANDEY, S. S., SINGH, S., PATHAK, C. \& TIWARI, B. S. 2018. "Programmed Cell Death: A Process of Death for Survival" - How Far Terminology Pertinent for Cell Death in Unicellular Organisms. J Cell Death, 11, 1179066018790259.

PEPPER, J. W., SHELTON, D. E., RASHIDI, A. \& DURAND, P. M. 2013. Are internal death-promoting mechanisms ever adaptive? Journal of Phylogenetics and Evolutionary Biology, 1:113.

PÉREZ MARTíN, J. M. 2008. Programmed cell death in protozoa, New York, N.Y., Springer-Verlag New York.

PRICE, G. R. 1972. Extension of covariance selection mathematics. Ann Hum Genet, 35, 485-90.

PRICE, G. R. 1995. The nature of selection. (Written circa 1971, published posthumously). J Theor Biol, 175, 389-96.

PROTO, W. R., COOMBS, G. H. \& MOTTRAM, J. C. 2013. Cell death in parasitic protozoa: regulated or incidental? Nat Rev Microbiol, 11, 58-66.

QUELLER, D. C. 1992. Quantitative genetics, inclusive fitness, and group selection. American naturalist, 139, 540-558.

RAMISETTY, B. C., NATARAJAN, B. \& SANTHOSH, R. S. 2015. mazEF-mediated programmed cell death in bacteria: "what is this?". Crit Rev Microbiol, 41, 89-100.

RAMISETTY, B. C. M. \& SANTHOSH, R. S. 2017. Endoribonuclease type II toxin-antitoxin systems: functional or selfish? Microbiology, 163, 931-939.

RAMSEY, G. \& PENCE, C. H. 2016. Chance in evolution, Chicago, University of Chicago Press.

RATCLIFF, W. C., DENISON, R. F., BORRELLO, M. \& TRAVISANO, M. 2012. Experimental evolution of multicellularity. Proceedings of the National Academy of Sciences, 109, 1595-1600.

RATEL, D., BOISSEAU, S., NASSER, V., BERGER, F. \& WION, D. 2001. Programmed cell death or cell death programme? That is the question. J Theor Biol, 208, 385-6.

REECE, S. E., POLLITT, L. C., COLEGRAVE, N. \& GARDNER, A. 2011. The meaning of death: evolution and ecology of apoptosis in protozoan parasites. PLoS Pathog, 7, e1002320.

REEVE, H. K. \& SHERMAN, P. W. 1993. Adaptation and the goals of evolutionary research. Quaterly review of biology, 68, 1-32.

REFARDT, D., BERGMILLER, T. \& KÜMMERLI, R. 2013. Altruism can evolve when relatedness is low: evidence from bacteria committing suicide upon phage infection. Proceedings of the Royal Society of London B: Biological Sciences, 280, 20123035.

ROSE, M. R. \& LAUDER, G. V. E. 1996. Adaptation, San Diego, CA, Academic press.

ROUGHGARDEN, J., GILBERT, S. F., ROSENBERG, E., ZILBER-ROSENBERG, I. \& LLOYD, E. A. 2017. Holobionts as Units of Selection and a Model of Their Population Dynamics and Evolution. Biological Theory, 13.

SANSOM, R. 2003. Constraining the adaptationism debate. Biology and Philosophy, 18, 493-512.

SATHE, S. \& DURAND, P. M. 2016. Cellular aggregation in Chlamydomonas (Chlorophyceae) is chimaeric and depends on traits like cell size and motility. . European Journal of Phycology, 51, 129-138.

SEGOVIA, M., HARAMATY, L., BERGES, J. A. \& FALKOWSKI, P. G. 2003. Cell death in the unicellular chlorophyte Dunaliella tertiolecta. A hypothesis on the evolution of apoptosis in higher plants and metazoans. Plant Physiol, 132, 99-105.

SOBER, E. 2006. Conceptual issues in evolutionary biology, Cambridge, Mass., MIT Press. 
SOBER, E. \& WILSON, D. S. 1994. A critical review of philosophical work on the units of selection problem. Philosophy of Science, 61, 534-555.

SOBER, E. \& WILSON, D. S. 1998. Unto others: the evolution and psychology of unselfish behavior, Cambridge MA, Harvard university press.

SUN, G. \& MONTELL, D. J. 2017. Q\&A: Cellular near death experiences-what is anastasis? BMC Biol, $15,92$.

UREN, A. G., O'ROURKE, K., ARAVIND, L. A., PISABARRO, M. T., SESHAGIRI, S., KOONIN, E. V. \& DIXIT, V. M. 2000. Identification of paracaspases and metacaspases: two ancient families of caspase-like proteins, one of which plays a key role in MALT Iymphoma. Mol Cell, 6, 961-7.

VAN VALEN, L. 2009. How ubiquitous is adaptation? A critique of the epiphenomenist program. Biology and Philosophy, 24, 267-280.

VAN ZANDBERGEN, G., BOLLINGER, A., WENZEL, A., KAMHAWI, S., VOLL, R., KLINGER, M., MÜLLER, A., HÖLSCHER, C., HERRMANN, M. \& SACKS, D. 2006. Leishmania disease development depends on the presence of apoptotic promastigotes in the virulent inoculum. Proceedings of the National Academy of Sciences, 103, 13837-13842.

VAN ZANDBERGEN, G., LUDER, C. G., HEUSSLER, V. \& DUSZENKO, M. 2010. Programmed cell death in unicellular parasites: a prerequisite for sustained infection? Trends Parasitol, 26, 477-83.

VARDI, A., BERMAN-FRANK, I., ROZENBERG, T., HADAS, O., KAPLAN, A. \& LEVINE, A. 1999. Programmed cell death of the dinoflagellate Peridinium gatunense is mediated by $\mathrm{CO}(2)$ limitation and oxidative stress. Curr Biol, 9, 1061-4.

VARDI, A., EISENSTADT, D., MURIK, O., BERMAN-FRANK, I., ZOHARY, T., LEVINE, A. \& KAPLAN, A. 2007. Synchronization of cell death in a dinoflagellate population is mediated by an excreted thiol protease. Environmental microbiology, 9, 360-369.

VARDI, A., HARAMATY, L., VAN MOOY, B. A., FREDRICKS, H. F., KIMMANCE, S. A., LARSEN, A. \& BIDLE, K. D. 2012. Host-virus dynamics and subcellular controls of cell fate in a natural coccolithophore population. Proc Natl Acad Sci U S A, 109, 19327-32.

VARDI, A., VAN MOOY, B. A., FREDRICKS, H. F., POPENDORF, K. J., OSSOLINSKI, J. E., HARAMATY, L. \& BIDLE, K. D. 2009. Viral glycosphingolipids induce lytic infection and cell death in marine phytoplankton. Science, 326, 861-5.

WILLIAMS, G. C. 1966. Adaptation and natural selection, Princeton, NJ, Princeton University Press.

YORDANOVA, Z. P., WOLTERING, E. J., KAPCHINA-TOTEVA, V. M. \& IAKIMOVA, E. T. 2013. Mastoparan-induced programmed cell death in the unicellular alga Chlamydomonas reinhardtii. Ann Bot, 111, 191-205.

ZUO, Z., ZHU, Y., BAI, Y. \& WANG, Y. 2012. Acetic acid-induced programmed cell death and release of volatile organic compounds in Chlamydomonas reinhardtii. Plant Physiol Biochem, 51, 17584.

ZUPPINI, A., ANDREOLI, C. \& BALDAN, B. 2007. Heat stress: an inducer of programmed cell death in Chlorella saccharophila. Plant Cell Physiol, 48, 1000-9. 